\title{
Gallbladder Cancer pTis TNM Finding v8
}

National Cancer Institute

\section{Source}

National Cancer Institute. Gallbladder Cancer pT is TNM Finding v8. NCI Thesaurus. Code C134646.

Gallbladder cancer with a finding of carcinoma in situ. (from AJCC 8th Ed.) 